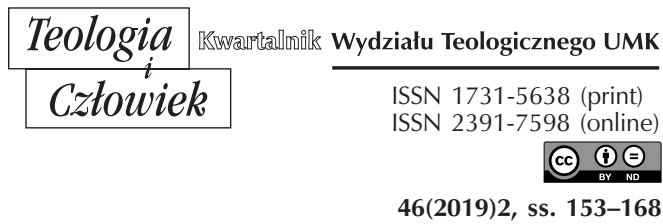

MIROSŁAW RUCKI

UNIWERSYTET TECHNOLOGICZNO-HUMANISTYCZNY

IM. KAZIMIERZA PUŁASKIEGO W RADOMIU

M.RUCKI@UTHRAD.PL

ORCID: 0000-0001-7666-7686

\title{
ILUZJE POLITYCZNE STWARZANE PRZEZ MISJONARZY WŚRÓD ASYRYJCZYKÓW W HAKKARI: RELACJA R. TERMENA I JEJ KONTEKST POLITYCZNO-RELIGIJNY
}

DOI: http://dx.doi.org/10.12775/TiCz.2019.020

Streszczenie. Celem opracowania jest ukazanie problemu religijno-politycznego ostatnich dziesięcioleci istnienia wspólnot chrześcijańskich w regionie Hakkari południowo-wschodniej Turcji przed ich totalną zagładą. Źródłem opracowania jest raport rosyjskiego generała Ryszarda Termena (1870-1937), który w latach 1905-1908 był wicekonsulem w wilajecie Wan. Znaczną część raportu stanowią opisy działalności misjonarzy rosyjskich (reprezentujących Kościół prawosławny), francuskich (Kościół katolicki), angielskich (Kościół anglikański) i amerykańskich (Kościoły protestanckie) wśród chrześcijańskiej ludności asyryjskiej regionu Hakkari.

Termen wskazuje, że Asyryjczycy należący do Kościoła Wschodu („niestoriańskiego") pomimo bardzo silnego przywiązania do swojej wiary i tradycji, chętnie zmieniali przynależność denominacyjną, kiedy widzieli nadzieję wsparcia politycznego. Po części zjawisko to było wynikiem politycznej natury islamu, który jako dominująca religia Turcji Osmańskiej nadawał chrześcijanom status obywateli drugiej kategorii. Wskutek dyskryminacji chrześcijan, korupcji urzędników i bezkarności band muzułmańskich Kurdów, Asyryjczycy w stanie skrajnej rozpaczy gotowi byli do masowej emigracji lub do powstania zbrojnego $\mathrm{w}$ sojuszu $\mathrm{z}$ dowolnym państwem prowadzącym wojnę przeciwko Turcji. Każda niemuzułmańska władza polityczna jawiła się im jako korzystna, o czym dobitnie świadczą niezwykle pozytywne wrażenia Asyryjczyków wyjeżdżających zarobkowo do Rosji. 
Innym ważnym elementem zmiany denominacji w celach politycznych było to, że Asyryjczycy uważali chrześcijaństwo za jednolitą religię, przejawiającą się w różnych formach. Za cenę krwi opierali się przyjęciu islamu, ale po kilka razy przechodzili na prawosławie, anglikanizm lub katolicyzm, kiedy widzieli płynące z tego korzyści materialne i polityczne.

I w końcu najważniejszy chyba problem religijno-politycznego charakteru misji był związany z tym, że na Zachodzie Kościół już nie miał takiego wpływu na politykę rządów, jak na Wschodzie, i często obietnice misjonarzy - zarówno te wyartykułowane, jak i te domniemane przez Asyryjczyków - były bez pokrycia. Skończyło się to katastrofą chrześcijaństwa w Hakkari, gdyż Asyryjczycy ulegli wpierw rozbiciu jedności religijnej, a potem zdradzeni przez polityczne władze Zachodu zostali zmasakrowani przez przeważające siły muzułmańskich Kurdów i Turków.

Słowa kluczowe: Asyryjczycy; Hakkari; misje; polityka.

Abstract. Political illusions as an effect of missions to Assyrians in Hakkari: report by R.Termen and its religious and political context. The objective of this paper is to highlight religious and political problem of last decades of the Christian communities in Hakkari region in South-Eastern Turkey before their total annihilation. The source is a report written by Russian general Richard Termen (1870-1937), who in the period 1905-1908 was a vice-consul in Ottoman province Van. Significant part of his report is dedicated to the activity of Christian missionaries of different denominations and countries, such as Russian Orthodox missionaries, French missionaries representing Roman Catholic Church, English (Anglican) missionaries and American missions of various protestan Churches, among Assyrian Christians in Hakkari.

General Termen emphasized that Assyrians who mainly belonged to the Church of East (so-called "nestorians") and felt strong ties with its history and traditions, willingly changed their denomination identity when it was to bring them political hopes. Partially, it was a result of political nature of Islam which dominated in Ottoman Empire and made Christians the second-class citizens. Severe discrimination, corruption of the Turkish state officers and endless violence from bands of Muslim Kurds made Assyrians so desperate that they were ready to the mass emigration or to war against Ottoman Turkey in alliance with any country. Any non-Muslim government appeared to be better than what they experienced, which was witnessed by the Assyrians who travelled to Russia for work.

Another important motivation for political change of religious denomination was their perception of Christianity as the uniform religion in different forms. Assyrians would rather die than embrace Islam, but readily became Russian Orthodox, Anglicans or Catholics subsequently for several times, when they felt some political or financial benefits.

And perhaps the most important political and religious problem of Western missions among Assyrians was that the Churches had very small impact on the governments in Europe and USA, much smaller than that in the Eastern world. As a result, 
many promises made by missionaries or expected by Assyrians were just in words. In fact, this phenomenon caused final catastrophe of Christianity in Hakkari region, because Assyrians first lost their religious unity, and then deceived by the political promises were left alone and massacred by overwhelming Muslim forces of Turks and Kurds.

Keywords: Assyrians; Hakkari; missiona; politics.

\section{WPROWADZENIE}

Pojęcie jedności w odniesieniu do Kościoła ma znaczenie chrystologiczne ${ }^{1}$, jest wręcz znakiem rozpoznawczym prawdziwego chrześcijaństwa w myśl słów Jezusa: „Po tym wszyscy poznają, żeście uczniami moimi, jeśli będziecie się wzajemnie miłowali” (J 13,35). Podziały i schizmy świadczą o tym, że coś niewłaściwego dzieje się w środowisku Kościoła ${ }^{2}$. Brak jedności i wzajemne zwalczanie się różnych denominacji chrześcijańskich od wieków są bolesną raną na Ciele Chrystusa.

Chrześcijaństwo ma charakter misyjny, co wynika z nauczania samego Jezusa Chrystusa, który dał swoim uczniom nakaz: „Idźcie więc i nauczajcie wszystkie narody, udzielając im chrztu w imię Ojca i Syna, i Ducha Świętego. Uczcie je zachowywać wszystko, co wam przykazałem. A oto Ja jestem $z$ wami przez wszystkie dni, aż do skończenia świata" (Mt 28,19-20). W nakazie tym można zauważyć cztery najważniejsze elementy, stanowiące cel misji chrześcijańskiej: nauczanie, udzielanie chrztu, zachowywanie przykazań oraz niepojęta, nadprzyrodzona, ale realna obecność Chrystusa wśród wiernych ${ }^{3}$. Misja międzykulturowa stanowiła podstawowy proces historyczny, kształtujący chrześcijaństwo jako religie światową ${ }^{4}$.

${ }^{1}$ R. Porada, Kościót jako sakrament zbawienia w świetle uzgodnienia Ku wspólnej wizji Kościoła, „Studia Oecumenica” 14 (2014), s. 63-81.

2 J. Fleetwood, The Christian's Dictionary; Or, Sure Guide to Divine Knowledge, London 1775.

3 Zagadnienie realnej obecności Chrystusa np. w Eucharystii zostało rozpatrzone w artykule: Mor Severius Moses, M. Rucki, M. Abdalla, Eucharystyczna obecność Chrystusa w rozumieniu liturgicznym Kościoła Antiocheńskiego, „Liturgia Sacra” 22 (2016), nr 1, s. 43-67.

${ }^{4}$ D.L. Robert, Christian Mission: How Christianity Became a World Religion, Oxford 2009, s. 2. 
Pod tym względem działalność misjonarzy katolickich i protestanckich wśród Asyryjczyków wygląda co najmniej jako nieporozumienie. Asyryjczycy bowiem wiernie trzymali się nauk apostolskich od I w., i sami na przestrzeni kilkunastu wieków prowadzili misje w całej Azji. Jednak wysiłki misji były skierowane właśnie do nich, podczas gdy np. katoliccy misjonarze mieli wręcz zakaz prowadzenia misji wśród muzułmanów ${ }^{5}$. Abdalla zwraca uwagę na stosowane przez misjonarzy europejskich i amerykańskich środki, wcale nie uświęcone przez szczytny cel, a także na opłakane skutki ich działalności na Bliskim Wschodzie ${ }^{6}$. W niniejszym studium, bazującym na relacji rosyjskiego wicekonsula R. Termena ${ }^{7}$, ukazano, jak praca misjonarzy, niezależnie od ich intencji, przyczyniła się do zagłady ludności asyryjskiej w regionie Hakkari.

\section{CHWALEBNA PRZESZZOŚĆ ASYRYJCZYKÓW}

Asyryjczycy będący obiektem działalności misyjnej, mieli za sobą długą i chwalebną historię, w której były całe wieki dominacji duchowej i kulturowej na ogromnych obszarach Bliskiego Wschodu Azji Środkowej, własne godne pozazdroszczenia osiągnięcia na polu misyjnym, a także znaczący wkład w rozwój budownictwa, architektury, nauk ścisłych, piśmiennictwa i innych dziedzin wiedzy. W historii Asyryjczyków wyodrębnia się następujące okresy:

1. Początki (ok. 2400 przed Chr.).

2. Pierwszy złoty wiek (2400-612 przed Chr.).

3. Pierwszy czarny okres (612 przed Chr. - 33 po Chr.).

4. Drugi złoty wiek (33-1300 po Chr.).

${ }^{5}$ L. Dzięgiel, O starożytnym kościele nestorian i jego spadkobiercach, „Znak” 35 (1983) 1, s. 36-60.

${ }^{6}$ M. Abdalla, Unickie Kościoły Bliskiego Wschodu: polityka Watykanu wobec chrześcijan nierzymskich, w: Polityczne uwarunkowania religii - Religijne uwarunkowania polityki, red. S. Dudra, R. Michalak, Ł. Młyńczyk, Zielona Góra 2017, s. 193-208.

7 Р.И. Термен, Отчет о поездке в санджак Хеккиари, Ванского вилайета, в 1907 году, Тифлис 1910.

${ }^{8}$ P. BetBasoo, Brief History of Assyrians, http://www.aina.org/brief.html (dostęp 12.04.2016). 
5. Drugi czarny okres (1300-1918 po Chr.).

6. Rozproszenie po świecie (1918 do czasów obecnych).

Pierwszy złoty wiek był związany z ustanowieniem mocnego państwa i objęciem władzy politycznej nad znaczną częścią ówczesnego świata' . W tym okresie, ok. 700 roku przed Chr., język aramejski jako język urzędowy (Reichsaramäisch, 700-200 p.n.e.) ${ }^{10}$ zdobył pozycję lingua franca na całym Wschodzie. O zasięgu tego języka świadczy fakt, że papirusy i ostrakony z IV wieku przed Chr. znaleziono w Egipcie, Arabii, Palestynie, Syrii, Iraku, Iranie, Anatolii, Armenii, Gruzji, Afganistanie i Pakistanie, zaś dwujęzyczne inskrypcje odkryto w Sardis (lidyjsko-aramejskie), Limyrze (aramejsko-greckie), Armazi (grecko-aramejskie) i Kandaharze

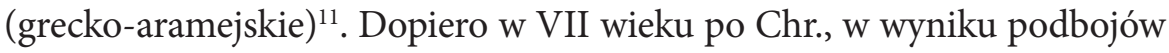
muzułmańskich i polityce arabizacji podbitych krajów i narodów, sytuacja się zmieniła i od tej pory pozycję tę zaczął zajmować na Wschodzie język arabski.

Podwaliny państwowości, prawa, nauki i cywilizacji Wschodu, założone przez Asyryjczyków w okresie świetności, znalazły kontynuację i rozwój w kolejnych następujących po sobie strukturach państwowych. Pomimo odsunięcia Asyryjczyków od władzy politycznej i okresów prześladowań, w ciągłej rywalizacji kultur narodowych zauważalna jest w tym okresie dominacja kultury asyryjskiej ${ }^{12}$. Jej rozkwit, nazwany przez BetBasoo drugim złotym wiekiem, wiąże się z przyjęciem chrześcijaństwa i rozwoju związanej z nim działalności misyjnej, naukowej i piśmienniczej ${ }^{13}$. Potoczny podkreśla, że „W ciągu pierwszych piętnastu lat [istnienia chrześcijaństwa] prawdziwym centrum chrześcijańskiej ekspansji

9 M. Rucki, M. Abdalla, Asyryjczycy - naród, język, wiara, „Teologia i Człowiek”, 39 (2017) 3, s. 199-219.

10 J.A. Fitzmyer, The phases of the Aramaic Languages, w: A Wandering Aramean: Collected Aramaic Essays, Grand Rapids 1997, s. 57-84.

${ }_{11}$ S.E. Fassberg, Judeo-Aramaic, w: Handbook of Jewish Languages, red. A.D. Rubin, L. Kahn, Leiden 2015, s. 64-108.

12 S. Parpola, Assyrians after Assyria, „Journal of Assyrian Academic Studies” 12 (1999) nr 2, s. 1-16.

${ }_{13}$ M. Rucki, Religijne uwarunkowania złotego wieku i przetrwania Asyryjczyków jako narodu bez państwa, w: Polityczne uwarunkowania religii - Religijne uwarunkowania polityki, red. S. Dudra, R. Michalak, Ł. Młyńczyk, Zielona Góra 2017, s. 177-191. 
była Syria - zarówno grecka, ze stolicą w Antiochii, jak i aramejska, ze stolica w Damaszku", a syryjskie miasta Edessa i Nisibis były znaczącymi ośrodkami chrześcijaństwa ${ }^{14}$. Wraz z rozwojem życia monastycznego liczne klasztory budowane przez Asyryjczyków stawały się ośrodkami życia duchowego, nauki i kultury ${ }^{15}$.

W wyniku schizmy po Soborze Efeskim (431 r.) i Chalcedońskim (451 r.) powstały dwa odrębne Kościoły, do których należeli Asyryjczycy: wschodni, niesłusznie nazywany „nestoriańskim”, i zachodni, równie niesłusznie nazwany ,jakobickim”. Nestoriusz bowiem nie był założycielem ani patriarchą "Kościoła Nestoriańskiego”16, a Jakub Baradeusz jedynie przyczynił się do przetrwania swojego Kościoła w czasie okrutnych prześladowań ze strony Bizancjum ${ }^{17}$. Paradoksalnie, schizma ta przyczyniła się do zdrowej rywalizacji i wpłynęła na rozwój zarówno piśmiennictwa syryjskiego ${ }^{18}$, jak i misji ${ }^{19}$.

Działalność misyjna Asyryjczyków wywołuje podziw z kilku powodów. Prowadzona była przez wiele wieków na ogromnych obszarach wśród bardzo odległych kulturowo i językowo narodów. Dzięki Asyryjskiemu Kościołowi Wschodu Ewangelia dotarła aż do wschodniego wybrzeża Chin. Emhardt i Lamsa, opisując dalekowschodnie misje „nestorian”, zaznaczają obecność biskupów asyryjskich w Persji już w V wieku (w Teheranie, Chorasanie, Isfahanie, Merwie i Heracie), w VI wieku w Indiach,

14 M. Potoczny, Rodziny liturgiczne chrześcijańskiego Wschodu - panorama, „Teologia i Człowiek” 25 (2014), nr 1, s. 165-185.

${ }_{15}$ M. Abdalla, M. Rucki, Klasztory jako ośrodki działalności pisarzy syriackich, „Studia Teologiczno-Historyczne Śląska Opolskiego” 36 (2016), nr 1, s. 129-152.

16 Pisze o tym patriarcha Kościoła „nestoriańskiego” Mar Abdiszo Bar Bericha w pracy Perła, której tłumaczenie na język angielski zostało opublikowane w książce: G.P. Badger, The Nestorians and their Rituals, vol. 2., London 1987, s. 380-422.

17 J.-N.M. Saint-Laurent, Missionary Stories and the Formation of the Syriac Churches, Oakland 2015, s. 96-98. Niestety, w polskiej literaturze przedmiotu można znaleźć błędne opinie, że był on właściwym założycielem Kościoła jakobickiego, np. E. Przekop, Zarys historyczny instytucji patriarchatu w Kościele wschodnim w I tysiącleciu, „Prawo Kanoniczne” 16 (1973) 1-2, s. 45-72.

${ }^{18}$ W. Witakowski, Geneza chrześcijańskiej kultury syryjskiej, „Studia Theologica Varsaviensia” 16 (1978) 1, s. 125-153.

${ }_{19}$ J.W. Żelazny, Monastycyzm syryjski i mezopotamski w ujęciu ks. Stefana Siwca, w: Historia monastycyzmu orientalnego, red. A. Uciecha, Katowice 2014, s. 59-69. 
w VII w Egipcie i na Cyprze, a następnie w Afganistanie, Turkiestanie i na Syberii; od VII wieku podejmowano systematyczne próby ewangelizacji Chin, a w 1265 roku administracja tego Kościoła obejmowała 25 prowincji azjatyckich, w których utworzono 70 biskupstw ${ }^{20}$. Dopiero Tamerlan zatrzymał rozwój Kościoła Wschodu, fizycznie masakrując wyznawców Chrystusa i niszcząc wszystko, co oni wytworzyli żmudną pracą ${ }^{21}$. Największe społeczności „nestoriańskie” przetrwały w niedostępnych górach, nazywanych m.in. „Górami Nestoriańskimi”22. Właśnie w tych górach, gdzie ostał się patriarchat Kościoła Wschodu, miała miejsce działalność misjonarzy, o której opowiada generał Termen.

\section{GENERAŁ TERMEN I JEGO RAPORT}

Termen Ryszard (a właściwie Richard), syn Józefa, 1870-1937, był Rosjaninem pochodzenia francuskiego. W swoim dziele nie omawia szczegółowo swojego wyznania, podkreśla tylko, że jest protestantem i nie identyfikuje się z rosyjskim prawosławiem. Frunze podaje, że służbę wojskową Termen rozpoczął mając 17 lat, ukończył szkołę artyleryjską św. Michała, akademię Sztabu Generalnego św. Mikołaja oraz kursy języków wschodnich $^{23}$. W roku 1915 otrzymał stopień generała-majora, i od 20 czerwca 1916 roku zajmował stanowisko dowódcy sztabu oddziału Azerbejdżańsko-Wanskiego.

Lewicki ${ }^{24}$ informuje, że od roku 1908 Termen był pułkownikiem, w latach 1912-1914 dowodził sztabem 52. dywizji piechoty, a w 1915 roku

20 W.Ch. Emhardt, G.M. Lamsa, The Oldest Christian People. New York: Macmillan\&Co., 1926, s. 64-65.

${ }^{21}$ Ch. Baumer, The Church of the East, London-New York 2008, s. 233.

${ }^{22}$ Taką nazwę stosował historyk asyryjski B. Arsanis mówiąc o górach położonych między Dyarbakirem na zachodzie, Koturem na północy, Urmią na wschodzie oraz Mosulem i Arbilem na południu, które dały schronienie Asyryjczykom (Б.Г. Арсанис, История ассирийеев в связи с курдами, Мосул 1922). Na Zachodzie takiej nazwy używał m. in. A.H. Layard (Nineveh and its remains, Vol. 1, New York 1850, s. 20) i J. Perkins (Missionary Life in Persia, Boston 1861, s. 140).

${ }_{23}$ М.В. Фрунзе, Неизвестное и забытое: публицистика, мемуары, документы, письма, Москва 1991, s. 238.

${ }_{24}$ В. Левицкий, На Кавказском фронте Первой мировой. Воспоминания капитана 155-го пехотного Кубинского полка, Москва 2015, przyрis 93. 
80. pułkiem piechoty. W 1915 roku otrzymał odznakę broni św. Jerzego i stopień generała-majora, po czym został wpisany na rezerwową listę członków sztabu Kaukaskiego obwodu wojskowego.

W 1901 roku Termen jako kapitan rozpoczął służbę na Kaukazie. W latach 1902-1903 zajmował stanowisko starszego oficera do zadań specjalnych. W 1904 roku otrzymał stopień podpułkownika i stanowisko sztab-oficera do zadań specjalnych przy dowódcy Kaukaskiego obwodu wojskowego. W kwietniu 1908 roku został przeniesiony na Syberię, gdzie była adiutantem sztabu obwodu Irkuckiego i później dowódcą sztabu 6 . dywizji Sybirskiej. W grudniu 1908 roku otrzymał stopień pułkownika i w 1912 roku został dowódcą sztabu 52. dywizji piechoty. Przez kilka miesięcy 1916 roku był też dowódcą sztabu gubernatora generalnego zajętej w czasie wojny części Turcji ${ }^{25}$.

W okresie 20.05.1905-12.04.1908 roku Termen w stopniu podpułkownika piastował stanowisko rosyjskiego wicekonsula $\mathrm{w}$ Turcji, w prowincji Wan ${ }^{26}$. Według ówczesnego podziału administracyjnego, miasto Wan stanowiło centrum wilajetu, podzielonego na dwa pomniejsze rejony - sandżak Hakkari, obejmujący południową część wilajetu, i sandżak podlegający pod Wan. Jak wielu dyplomatów z Zachodu, zbierał informacje o militarnym potencjale Turcji z uwzględnieniem zamiaru Rosji wszczęcia kolejnej wojny. XIX wiek zaznaczył się pasmem zwycięstw armii rosyjskiej nad wojskami osmańskimi, co wpłynęło również na zmiany w polityce religijnej patriarchatu moskiewskiego $\mathrm{w}$ stosunku do innych wspólnot chrześcijańskich ${ }^{27}$. Dlatego też, oprócz kwestii militarnych i dyplomatycznych, Termen musiał zwrócić uwagę na działalność wszelkich misji, w tym rosyjskiej misji prawosławnej.

Nadmienić należy, że sukcesy Rosji niepokoiły Austrię i Wielką Brytanię, które to mocarstwa były zainteresowane w osłabieniu Turcji, ale

${ }_{25}$ Русская армия в Великой войне, http://www.grwar.ru/persons/persons. html?id=1469 (dostęp 22.06.2018).

26 Take dane podaje Wikipedia https://ru.wikipedia.org/wiki/Термен,_Ричард_ Иосифович (dostęp 22.06.2018); dotarcie do bardziej wiarygodnych źródeł jest utrudnione.

27 Dobrym opracowaniem tego tematu jest książka L. Gerd, Russian Policy in the Orthodox East: The Patriarchate of Constantinople (1878-1914), Warsaw-Berlin 2014. 
nie w umocnieniu pozycji Rosji na Wschodzie ${ }^{28}$. Sytuacja była tak napięta, że w 1878 roku mogło dojść do wojny między Rosją i Anglią, mimo że oba kraje były zainteresowane obaleniem rządów Porty ${ }^{29}$. Na początku XX wieku, kiedy Termen był wicekonsulem w Wanie, brytyjskie, francuskie, niemieckie i angielskie służby dyplomatyczne prowadziły własną politykę, usiłując pozyskać sympatie ludności w imperium Osmańskim w celu umocnienia własnej pozycji politycznej, czego narzędziem stały się misje religijne.

W roku 1906 Termen odbył kilka podróży do sandżaku Hakkari, dokładnie notując potrzebne dane dotyczące ludności, dróg, wzajemnych relacji między poszczególnymi grupami narodowościowymi i wyznaniowymi, a także działalności dyplomacji i misjonarzy z różnych krajów. Raport, wykorzystany do niniejszego studium, wydrukowano w 1910 roku w sztabie Kaukaskiego Okręgu Wojskowego w Tyflisie. Zawiera wiadomości geograficzne, rozdział etnograficzny podzielony na części poświęcone Kurdom i Asyryjczykom, osobny rozdział poświęcony rekrutacji do pułków Hamidiye i ich funkcjonowaniu, a także rozdział „Kurdowie, Ormianie i Asyryjczycy regionu Wan-Bitlis ${ }^{30}$ oraz ich stosunek do Rosji w razie wojny z Turcją". Na końcu, w postaci aneksów, umieszczono dane statystyczne dotyczące ludności asyryjskiej i kurdyjskiej, a także opis 14 tras, przebytych przez Termena, ze szczególnym uwzględnieniem ich przydatności do przemarszu wojsk. Rozdział poświęcony Asyryjczykom zawiera części dotyczące działalności misjonarzy katolickich, anglikańskich i prawosławnych, a także protestanckich misjonarzy z USA. W pracy autor przytacza i aktualizuje dane opublikowane przez swoich poprzedników, którzy zbierali informacje dla wywiadu rosyjskiego i opisywali ten

${ }^{28}$ Zob. np. M. Roberts, Britain, 1846-1964: The Challenge of Change, Oxford 2001, s. 35.

29 Zob. np. M.D. Stojanović, The Great Powers and the Balkans, 1875-1878, Cambridge 1939 (reprint 1968), s. 252-257.

30 Termen ma na myśli dwie prowincji Turcji Osmańskiej: Wan i Bitlis. Bitlis jest miastem położonym na wschód od jeziora Wan. W XIX wieku było centrum wilajetu (prowincji), w którym mieszkało ok. 382 tys. osób, z czego 180 tys. było Ormian. Pomimo masakr w latach 1894-1896 Ormianie aż do 1915 roku stanowili najbardziej liczną grupę etniczną prowincji Bitlis (Акопян T. Х., Города исторической Армении, Т. 1, Айастан 1987, s. 98-104). 
region: przede wszystkim Majewskiego ${ }^{31}$ i Awerianowa ${ }^{32}$. Podobne raporty wojskowe, opisujące region Hakkari zamieszkały przez Asyryjczyków, były opracowywane również przez dyplomatów brytyjskich ${ }^{33}$.

Termen, opisując Asyryjczyków, używa w swojej publikacji nazwy Ajsor (Ajsorowie). Uzasadnia to następująco:

Nazwa „Asuri” ewidentnie pochodząca od nazwy „Asyryjczycy” była używana w stosunku do nich przez wszystkie czasy, i kurdyjski historyk końca XVI w. Szeref-ud-Din ${ }^{34}$ pisze, że w XV w. w Dezie mieszkało plemię niewiernych chrześcijan nazywanych Asurami. W języku rosyjskim nazwa ta przekształciła się w „Ajsorowie”, które to brzmienie uważam za najbardziej odpowiednie dla oznaczenia całego narodu.

Dziewiętnastowieczny rosyjski profesor Bołotow ( $† 1900)$ jednak twierdził, że Asyryjczycy „nazywają siebie Aturaje. Syro-Chaldejczycy pragną - i mają prawo tego wymagać - by ich nie nazywano Ajsorami. Wyraz «Ajsor» bowiem jest jedynie ormiańskim tłumaczeniem wyrazu "Asyria», która po aramejsku nazywa się אתור Ath $\mathrm{u}^{\mathrm{u}}$ lub Athôr" ${ }^{35}$. Według rosyjskiego rocznika etnograficznego z początku XX wieku ${ }^{36}$, Asyryjczycy (Assurowie lub Ajsorowie) nazywali siebie Syryjczykami lub Chaldejczykami (unici), a nazwę „Ajsor” nadali im Ormianie. Publikacja ta zaznacza,

31 В.Т. Маевский, Ванский вилает: Военно-статистическое описание, Тифлис 1901.

${ }^{32}$ П.И. Аверьянов, Курды в войнах России с Персией и Турицей в течение ХІХ столетия, Тифлис 1900.

${ }^{33}$ Np. A Handbook of Mesopotamia, Vol. IV: Northern Mesopotamia and Central Kurdistan, Admiralty War Staff, Intelligence Division, April 1917.

${ }^{34}$ Prawdopodobnie chodzi o kurdyjskiego emira Szaraf ad-Dina (Szaraf Chana) Bitlisi’ego (1543-1603), który napisał w roku 1597 historie Kurdów pt. Szarafnama w języku perskim. Praca w dwujęzycznej wersji persko-angielskiej została wydana w USA (The Sharafnama: or the History of the Kurdish Nation, New York 2015), natomiast gen. Termen z pewnością zapoznał się z nią dzięki wydaniu francuskiemu wydrukowanemu w Petersburgu (F. B. Charmoy, Chèref-nâmah ou fastes de la nation kurde, 2 vols., St. Petersburg 1868-1875.).

35 Болотов В.В., Из истории церкви сиро-персидской, С.-Петербург 1901, s. 111.

36 „Этнографическое обозрение. Год 15-№2”, ред. В. Миллер, Москва 1903, s. 171. 
że według własnego rozumienia, Asyryjczycy pochodzą w prostej linii od Assura (Aszszura), wnuka Noego (por. Rdz 10,22). W niniejszej analizie, ze względu na ciągłość pokoleniową tego narodu od czasu starożytnego państwa Asyryjskiego, przyjmuję, że w języku polskim najlepszym odpowiednikiem terminu użytego przez gen. Termena jest określenie "Asyryjczycy”.

\section{STOSUNEK ASYRYJCZYKÓW DO MISJI}

Wicekonsul Ryszard Termen negatywnie oceniał działalność wszystkich misji bez wyjątku. Wielokrotnie wskazywał na polityczny charakter tych misji oraz na fakt, że misjonarze usiłowali zdyskredytować działalność innych misjonarzy. Na przykład Anglia widziała zagrożenie w poczynaniach Rosji, dlatego angielscy misjonarze głosili w kościołach kazania antyrosyjskie. Turcja z kolei widziała dla siebie pożytek w osłabieniu wspólnoty chrześcijańskiej, dlatego wspierała misje, które godziły w jedność Asyryjczyków i mnożyły podziały. Według wicekonsula, również działalność oświatowa misjonarzy wniosła w góry poróżnienie, gdyż pod wpływem ich nauczania młodzież liberalna zaczęła dążyć do tego, by zwracać się o rozstrzygnięcie sporów do władz tureckich, a nie do swojego patriarchy Mar Szymuna. Poza tym, duch krytykanctwa misjonarzy protestanckich przenikał do treści nauczania, w związku z czym szkoła nie uczyła młodych szacunku wobec autorytetu Mar-Szymuna, a także rozwijała ich krytyczny stosunek do kwestii wiary. Termen przytacza następujące wypowiedzi Asyryjczyków:

„Po co do nas przyszliście? Jeśli przyszliście tylko po to, by popatrzeć na naszą trudną sytuację, albo po to, by podkopywać naszą religię, to nie jesteście nam potrzebni. Ale jeśli chcecie pomóc nam urządzić szkoły realne, to z radością was powitamy i będziemy wam szczerze wdzięczni". W innym miejscu mi powiedziano: „Po co te szkoły misjonarskie? One tylko przygotowują księży i nie dają absolutnie żadnej wiedzy. Księży mamy, i oni mogą nauczać młodzież Prawa Bożego. Ale my chcemy, by nasza młodzież znała języki obce i zdobyła wykształcenie, żeby jadąc za granicę na zarobki mogła wykorzystać w praktyce swoją wiedzę. A szkoły misjonarskie niczego nie nauczają. Dzieci, które je kończą, nie znają porządnie żadnego języka”. 
Termen odnotowywał też negatywny stosunek Asyryjczyków do działalności misjonarzy. Pisał: „mieszkańcy skarżyli się, że misjonarze przynieśli im nieszczęście, że przez nich władze tureckie stały się względem nich bardziej nietolerancyjne”. Każdy cudzoziemiec pojawiający się w górach był traktowany nieufnie, ponieważ zazwyczaj był to misjonarz.

Będąc od prawie dwóch tysiącleci narodem chrześcijańskim, który zaniósł Chrystusa wielu pogańskim narodom w całej Azji, Asyryjczycy nie chcieli, by wśród nich prowadzono działalność misyjną: „Religia, przez którą wiele wycierpieli, głęboko w nich się zakorzeniła. Są fanatyczni, szczególnie ci mieszkający w górach, i nie znoszą misjonarzy”. W jednym z przytoczonych zdarzeń, jakie miało miejsce w czasie podróży Termena po sandżaku Hakkari, wzięto go za misjonarza i obrabowano. Dopiero kiedy napastnicy przekonali się, że jest wicekonsulem Rosji i nie zajmuje się sprawami religijnymi, zwrócili mu wszystko i przepraszając żalili się na misjonarzy.

Opisując domy Asyryjczyków, Termen zauważa, że na zimę otwory okienne są zaklejane papierem namoczonym w oliwie, przy czym przeważnie do tego celu wykorzystuje się broszurki rozdawane przez misjonarzy.

Sam Termen ubolewał nad tym, że działalność misji prawosławnej nie jest zależna od wicekonsulatu, i zniechęcał Asyryjczyków do przyjęcia zwierzchnictwa Patriarchatu Moskiewskiego. Opisał taką sytuację:

Nestorianie z Saraju już od dawna zwracają się do wicekonsulatu z prośbą o przyjęcie ich do [rosyjskiego] Kościoła prawosławnego. Kiedy przyszli do mnie z tym w jesieni 1906 r., otwarcie spytałem, w jakim celu chcą przyjąć prawosławie. Odpowiedzieli, że w celu uzyskania patronatu i troski ze strony Rosji. Kiedy powiedziałem, że opieka nad poddanymi obcego kraju jest bardzo trudna, odpowiedzieli, że w takim razie nie chcą zmieniać religii, bo każdy ma religię w sercu. Mieli rację. Wszystkie zmiany wyznania są tylko zewnętrzne, z nazwy, i kiedy pojawia się bardziej korzystna propozycja, oni z łatwością powtórnie zmieniają wyznanie, a w duchu pozostają tacy, jakimi byli.

Absolutnie nie chcąc przechodzić na islam, Asyryjczycy gotowi byli zmieniać przynależność denominacyjną w zależności od płynących z tego korzyści. Nie chcieli jednak przyjmować nowej wiary bez politycznego lub 
finansowego wsparcia. Ci, dla których przejście na katolicyzm przyniosło korzyści (księża otrzymujący pensje i nauczyciele w szkołach), "pozostają katolikami i zapewniają misjonarzy, że katolicyzm rośnie w siłę", ale $\mathrm{w}$ rzeczywistości robią to tylko po to, by nadal otrzymywać pomoc materialną. Termen zauważa, że praktycznie wszystkie misje $\mathrm{z}$ wyjątkiem anglikańskich podkopują władzę patriarchy Mar Szymuna, wyrządzając wielką szkodę Asyryjczykom.

Dobitnym przykładem poróżnienia generowanego przez misjonarzy jest przejście jednego z biskupów Urmii na prawosławie. Termen relacjonuje, że na naradzie w Urmii kilka lat wcześniej biskup Mar-Jonasz zaczął dyskutować z misjonarzami anglikańskimi, i mister Browne (główny misjonarz) spoliczkował go. $\mathrm{Z}$ tego powodu biskup zwrócił się do duchowieństwa rosyjskiego $\mathrm{z}$ prośbą o przyjęcie prawosławia, i w ten sposób wraz ze sporą częścią Asyryjczyków Urmii został prawosławnym.

Niektórzy Asyryjczycy już wcześniej formalnie przyjęli prawosławie w czasie pobytu w Rosji, ale faktycznie pozostali nestorianami. Termen odnotowuje: „teraz chętnie są gotowi przyjąć prawosławie powtórnie w zamian za istotne korzyści”.

Podsumowując, Asyryjczycy nie traktowali misji chrześcijańskich jako szansy na wewnętrzną przemianę lub rozwój duchowy, i nie uważali, że głoszone im nowe doktryny są lepsze od tych znanych im od wieków. Mieli jednak nadzieję, że misjonarze reprezentujący mocarstwa chrześcijańskie pomogą im wyrwać się z opresji władców muzułmańskich zarówno politycznej, jak i religijnej. Żyjąc bowiem pod jarzmem islamu, odbierali władzę polityczną w ścisłym związku z władzą religijną, zgodnie z doktryną Mahometa. Podróżując do Rosji lub do Europy w celach zarobkowych, odbierali panujące tam warunki jako bezpośredni wynik wyznawanej przez Europejczyków wiary w Chrystusa i nie zagłębiali się w niuanse oddzielenia religii od państwa, które już w Europie się dokonywały. Każda władza, byle nie muzułmańska, jawiła im się jako lepsza. Nawet Rosja, w której panowała samowola urzędników i łapówkarstwo, w porównaniu do Persji czy Turcji była dla nich wzorem uczciwości, gdzie urzędnik sprawiedliwie rozstrzygał sprawy sporne. Dlatego też zdesperowani Asyryjczycy byli gotowi nawet do wszczęcia powstania, jak relacjonuje Termen: 
[Asyryjczycy] ciągle marzą o przywróceniu dawnego dobrobytu, ale są przekonani, że będzie to możliwe jedynie wraz z przywróceniem w kraju władz chrześcijańskich. Oczywiście, największe nadzieje wiążą z Rosją. Zwycięskie wojny, jakie prowadziła Rosja z Turcją, za każdym razem poruszały ich. Oczekiwali oni, że Rosjanie przyjdą do prowincji Wan i wybawią ich od ucisku tureckiego, i byli gotowi wzniecić powstanie, by pomóc wybawicielom.

Rozczarowanie następowało zawsze, kiedy okazywało się, że misje chrześcijańskie nie reprezentują władz swoich krajów i nie mogą spełnić żadnych oczekiwań politycznych.

\section{PODSUMOWANIE}

Na podstawie obrazu odmalowanego przez Termena, z uwzględnieniem innych źródeł, można stwierdzić, że działalność misjonarzy przyczyniła się do zagłady Asyryjczyków w górskim regionie Hakkari. Najbardziej destruktywnym elementem ich działalności było podkopanie autorytetu patriarchy Mar Szymuna i zburzenie jedności Asyryjczyków, które doprowadziło do znacznego ich osłabienia. Drugim problemem były obietnice bez pokrycia, które stwarzały iluzje braterskiej pomocy ze strony chrześcijańskich narodów i ostatecznie prowadziły do rozczarowania.

Oprócz tego misjonarze, realizując cele polityczne swoich krajów, bardziej lub mniej świadomie włączali się w grę polityczną, której celem wcale nie było wyzwolenie Asyryjczyków z opresji, na które ci ostatni najbardziej liczyli. Pomimo deklarowanych celów misji - m.in. wzbudzenie w Asyryjczykach szczerej wiary - uciekano się do takich metod, jak przekupywanie, skłócanie, rozpowszechnianie plotek i oszczerstw itp. Wszystkie misje ewidentnie odniosły porażkę, ponieważ żadna z denominacji nie była w stanie przekonać Asyryjczyków do swojego nauczania tak, by przyjęli je całym sercem. Odwrotnie, oferty misjonarzy uczyły szczerych wyznawców Chrystusa, że można przechodzić z Kościoła do Kościoła, jeśli się otrzyma więcej korzyści.

Największą porażkę odnieśli Asyryjczycy, którzy licząc na pomoc bratnich narodów chrześcijańskich dali się wciągnąć $\mathrm{w}$ grę polityczną mocarstw Zachodu na Bliskim Wschodzie. Zapłacili za to wysoką cenę 
w postaci fizycznej eksterminacji praktycznie całej ludności chrześcijańskiej sandżaku Hakkari. Przewidując negatywne skutki działalności misjonarzy, wicekonsul Termen nie był w stanie nawet sobie wyobrazić ogromu nadciągającej tragedii.

\section{LITERATURA}

A Handbook of Mesopotamia, Vol. IV: Northern Mesopotamia and Central Kurdistan, Admiralty War Staff, Intelligence Division, April 1917.

Abdalla M., Rucki M., Klasztory jako ośrodki działalności pisarzy syriackich, „Studia Teologiczno-Historyczne Śląska Opolskiego" 36 (2016), nr 1, s. 129-152.

Abdalla M., Unickie Kościoły Bliskiego Wschodu: polityka Watykanu wobec chrześcijan nierzymskich, w: Polityczne uwarunkowania religii - Religijne uwarunkowania polityki, red. S. Dudra, R. Michalak, Ł. Młyńczyk, Zielona Góra 2017, s. 193-208. Akopian T.H., Cities of the historical Armenia, vol. 1, Ayastan 1987 [in Russian].

Arsanis B.G., History of Assyrians in relation with Kurds, Mosul 1922 [in Russian].

Averianov P.I., Kurds in the Russian wars with Persia and Turkey during 19th century, Tiflis 1900 [in Russian].

Badger G.P., The Nestorians and their Rituals, vol. 2., London 1987.

Baumer Ch., The Church of the East, London - New York 2008.

BetBasoo P., Brief History of Assyrians, http://www.aina.org/brief.html dostęp 12.04.2016 r. Bolotov V.V., From the Syro-Persian Church history, Sankt-Petersburg 1901 [in Russian]. Dzięgiel L., O starożytnym kościele nestorian i jego spadkobiercach, „Znak” 35 (1983) 1, s. $36-60$.

Emhardt W.Ch., Lamsa G.M., The Oldest Christian People, New York 1926.

Fassberg S.E., Judeo-Aramaic, in: Handbook of Jewish Languages, red. A.D. Rubin, L. Kahn, Leiden 2015, s. 64-108.

Fitzmyer J.A., The phases of the Aramaic Languages, in: A Wandering Aramean: Collected Aramaic Essays, Grand Rapids 1997, s. 57-84.

Fleetwood J., The Christian's Dictionary; Or, Sure Guide to Divine Knowledge, London 1775 .

Frunze M.V., Unknown and forgotten: articles, memoirs, documents, letters, Moscow 1991 [in Russian].

Gerd L., Russian Policy in the Orthodox East: The Patriarchate of Constantinople (1878-1914), Warsaw - Berlin 2014.

Layard A.H., Nineveh and its remains, Vol. 1, New York 1850.

Levitsky V., In the Caucasus frontline of the first world war: Memoirs of Captain of 155th Cuban Infantry Regiment, Moscow 2015 [in Russian].

Mayevsky V.T., Vilayet of Van: Military statistical description, Tiflis 1901 [in Russian]. 
Mor Severius Moses, Rucki M., Abdalla M., Eucharystyczna obecność Chrystusa w rozumieniu liturgicznym Kościoła Antiocheńskiego, „Liturgia Sacra” 22 (2016), nr 1, s. 43-67.

Parpola S., Assyrians after Assyria, „Journal of Assyrian Academic Studies” 12 (1999) nr 2, s. 1-16.

Perkins J., Missionary Life in Persia, Boston 1861.

Porada R., Kościót jako sakrament zbawienia w świetle uzgodnienia Ku wspólnej wizji Kościoła, „Studia Oecumenica” 14(2014), s. 63-81.

Potoczny M., Rodziny liturgiczne chrześcijańskiego Wschodu - panorama, „Teologia i Człowiek" 25 (2014), nr 1, s. 165-185.

Przekop E., Zarys historyczny instytucji patriarchatu w Kościele wschodnim w I tysiącleciu, „Prawo Kanoniczne” 16 (1973) 1-2, s. 45-72.

Robert D.L., Christian Mission: How Christianity Became a World Religion, Oxford 2009.

Roberts M., Britain, 1846-1964: The Challenge of Change, Oxford 2001.

Rucki M., Abdalla M., Asyryjczycy - naród, język, wiara, „Teologia i człowiek”, 39 (2017) 3, s. 199-219.

Rucki M., Religijne uwarunkowania złotego wieku i przetrwania Asyryjczyków jako narodu bez państwa, w: Polityczne uwarunkowania religii - Religijne uwarunkowania polityki, red. S. Dudra, R. Michalak, Ł. Młyńczyk, Zielona Góra 2017, s. 177-191.

Russian Army in the Great War [in Russian], http://www.grwar.ru/persons/persons.html?id=1469 dostęp 22.06.2018 r.

Saint-Laurent J.-N.M., Missionary Stories and the Formation of the Syriac Churches, Oakland 2015,

Stojanović M.D., The Great Powers and the Balkans, 1875-1878, Cambridge 1939 (reprint 1968).

Termen R.I., Report from the trip to sanjak Hekkiari of Van vulayet in 1907, Tiflis 1910 [in Russian].

Termen Richard son of Joseph [in Russian], https://ru.wikipedia.org/wiki/Термен, Ричард_Иосифович dostęp 22.06.2018 r.

Witakowski W., Geneza chrześcijańskiej kultury syryjskiej, „Studia Theologica Varsaviensia” 16 (1978) 1, s. 125-153.

Żelazny J.W., Monastycyzm syryjski i mezopotamski w ujęciu ks. Stefana Siwca, w: Historia monastycyzmu orientalnego, red. A. Uciecha, Katowice 2014, s. 59-69. 